\title{
Microcapillary sign of flap alignment in femtosecond laser-assisted in situ keratomileusis
}

This article was published in the following Dove Press journal:

Clinical Ophthalmology

18 October 2016

Number of times this article has been viewed

\author{
Fathy Fawzy,2 \\ Sherine S Wahba 1,3 \\ Nader Fawzy ${ }^{1,4}$ \\ 'AI Watany Eye Hospital, \\ ${ }^{2}$ Ophthalmology Department, Military \\ Medical Academy, ${ }^{3}$ Ophthalmology \\ Department, Ain Shams University, \\ Cairo, Egypt; ${ }^{4}$ Sehkraft Augenzentrum, \\ Cologne, Germany
}

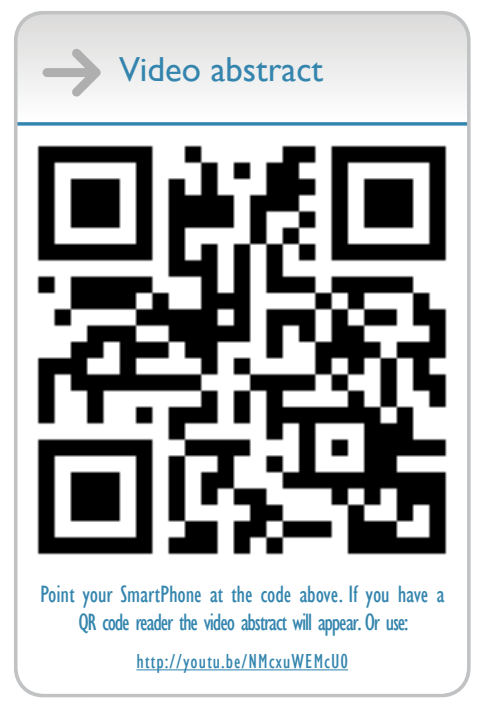

Correspondence: Nader Fawzy Alwatany Eye Hospital, 21 I Elhegaz Street, Heliopolis, Cairo II35I, Egypt Email nader.fawzy@alwatany.net.eg

\begin{abstract}
We present an observational sign that ensures perfect alignment during femtosecond laser-assisted in situ keratomileusis (FS LASIK). Alignment is assured when a microsponge is used to dry the flap and the area of dryness exceeds the area of direct touch of the microsponge. The area might even reach the whole circumference of the flap at the first touch. This sign of alignment can be explained by microcapillary action. This sign was not elicited in flaps created by a microkeratome.
\end{abstract}

Keywords: capillarity, femtosecond LASIK flap, corneal flap alignment

\section{Introduction}

Capillary action, or capillarity, is the ability of a liquid to flow in narrow spaces without the assistance of, and in opposition to, external forces like gravity. This effect can be seen in the drawing up of liquids in a thin tube and in porous materials such as paper. ${ }^{1}$ When a narrow tube is brought in contact with a mostly wetting liquid, some of the liquid rises inside the tube. This is a well-known manifestation of capillarity. Leonardo da Vinci (1452-1519 AD) was the first to observe this phenomenon. ${ }^{1}$ In 1670 AD, Giovanni Borelli demonstrated that the height reached by a liquid is inversely proportional to the radius of the tube. ${ }^{1}$ The height $(h)$ of a liquid column is given by: ${ }^{2}$

$$
h=\frac{2 \gamma \cos \theta}{p g r}
$$

where $\gamma$ is the liquid-air surface tension (force/unit length), $\vartheta$ is the contact angle, $\rho$ is the density of liquid (mass/volume), $g$ is the local acceleration due to gravity (length/ square of time), and $r$ is the radius of the tube (length). Thus, " $h$ " is inversely proportional to " $r$ ". Hence, the capillary action is more evident when the tube (or gutter) is narrower. In any wetting case, the liquid will rise in a tube until the force acting to pull the liquid upward is balanced by the weight of the column of liquid supported in the tube..$^{3,4}$

Femtosecond (FS) laser was first introduced in 2001. ${ }^{5}$ This technique uses an infrared beam of light to precisely separate tissue through a process called photodisruption, by generating pulses as short as one-quadrillionth of a second $\left(10^{-15}=\right.$ femtosecond $)$. The most popular use of the FS laser is to create a corneal flap in laser-assisted in situ keratomileusis (LASIK), eliminating the use and risk of a microkeratome and blade and increasing the overall safety, precision, and accuracy. ${ }^{6}$ The precision of the FS laser helps to create flaps of exact size, shape, and depth and markedly reduces the risk of blade-related flap complications such as free caps, buttonholes, and incomplete or 
decentered flaps. ${ }^{6}$ We present an observational sign to ensure perfect alignment of the FS LASIK flap that is explained by capillary action.

\section{Materials and methods}

Using the FS200 FL device (WaveLight ${ }^{\circledR}$; Alcon Labs, Fort Worth, TX, USA) and after docking, the flap was created using the following energy parameters for the bed cut: pulse energy, $0.8 \mu \mathrm{J}$; spot separation, $7.5 \mu \mathrm{m}$; and line separation, $7.5 \mu \mathrm{m}$. The parameters for the side cut were: pulse energy, $0.8 \mu \mathrm{J}$; spot separation, $5.0 \mu \mathrm{m}$; and line separation, $3.0 \mu \mathrm{m}$. The parameters for the canal cut were: pulse energy, $0.8 \mu \mathrm{J}$. The flap diameter was $9.0 \mathrm{~mm}$, with a $120 \mu \mathrm{m}$ thickness and $110^{\circ}$ side-cut angle. The hinge position was superior with a $50^{\circ}$ hinge angle. Then, the bed was ablated using an Excimer Laser EX500 (WaveLight; Alcon Labs). The flap was repositioned and balanced salt solution (BSS) was used for copious irrigation of the interface.

There are three steps to elicit the observational sign. First, we used an applanator lens and pushed the lens to the center of the cornea, to applanate the flap onto the stromal bed. This was followed by drying the conjunctiva far from the corneal surface. Finally, we used a dry microsponge at one side just temporal or nasal to the flap hinge along the corneal gutter. The gutter between the flap edge and the peripheral cornea is very thin and regular and acts as a microcapillary tube. Due to capillary action, the area of dryness should exceed the area of direct touch of the microsponge, and might even reach the whole circumference of the flap at the first touch (Figure 1). This is the microcapillary sign of perfect alignment (Video S1).

This microcapillary sign of perfect alignment ensures that there is precise and perfect flap alignment. In addition, the

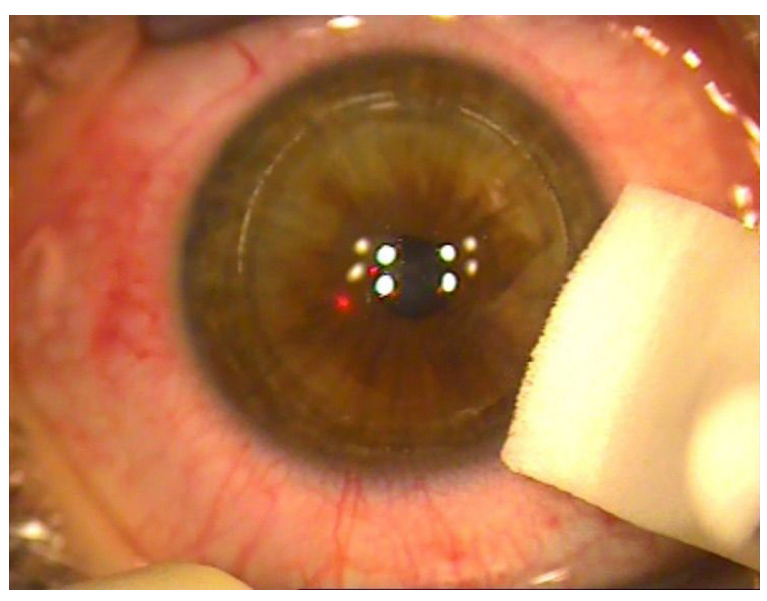

Figure I FS LASIK demonstrating Fawzy alignment sign.

Abbreviation: FS LASIK, femtosecond laser-assisted in situ keratomileusis. thin regular gutter between the flap and uncut surrounding cornea implies minimal, if any, tissue loss and a centered flap reposition. Finally, this sign assures a low incidence of flap complications (flap striae and early flap dislocations), which may occur with a wide or irregular gutter when using a microkeratome. This sign was not elicited in flaps created by a microkeratome due to the large and relatively less regular width of the gutter.

\section{Discussion}

The FS LASIK technique is the new trend in refractive surgery procedures. However, some of the refractive surgeons are still using the mechanical microkeratome. A critical step of LASIK surgery is the creation of the corneal flap. The mechanical microkeratome uses shear force while traveling across the corneal stroma with an oscillating blade to create a flap. ${ }^{7}$ In a retrospective study of 28,530 primary LASIK cases, Jacobs and Taravella ${ }^{8}$ reported a $0.302 \%$ total intraoperative complication rate using the Automated Corneal Shaper and Hansatome microkeratomes. Complications included partial flaps $(0.099 \%)$, buttonholes $(0.070 \%)$, thin or irregular flaps $(0.087 \%)$, and free flaps $(0.012 \%)$. In a cadaveric study, Sarayba et $\mathrm{al}^{9}$ evaluated the stromal bed quality produced by the Hansatome microkeratome with a $160 \mu \mathrm{m}$ head and IntraLase 15 and $30 \mathrm{kHz}$ FS laser with a $110 \mu \mathrm{m}$ thickness using scanning electron microscopy. They found that the $30 \mathrm{kHz}$ IntraLase created a smoother stromal bed compared with the $15 \mathrm{kHz}$ IntraLase and Hansatome due to a tighter spot/line separation and lower energy per pulse. Kim et $\mathrm{al}^{10}$ showed a highly reproducible flap thickness with IntraLase, as measured by optical coherence tomography (OCT). Ahn et al ${ }^{11}$ evaluated the thickness and side-cut angle of LASIK flaps created by one of three FS lasers or a microkeratome using Fourier-domain OCT. He reported that the flap morphology in the three FS laser systems appeared to be generally superior to the microkeratome system.

In our study, we support the superior results of FS LASIK shown by the previous studies using the microcapillary sign of perfect alignment. This sign ensures perfect and precise alignment of the FS LASIK flaps. The sign would not appear in microkeratome flaps. Also, this sign would not show if there is a displacement or a kink in the FS LASIK flap, which should be addressed until the sign can be elicited.

Perez et $\mathrm{al}^{12}$ reported a tight linear correlation between the decrease in water content and increase in adhesive force $\left(R^{2}=0.3355\right)$. They suggested that drying increases the stromal-to-stromal adhesion. Hence, our study confirmed that the gutter acts as a microcapillary tube, which means the bed cut is also a microcapillary space since both are cut using the 
same technology. Eliciting the microcapillary sign of perfect alignment will ensure pulling the BSS from underneath the flap, helping not only flap alignment but also adhesion to the bed, and decreasing the risk of postoperative slippage or striae. Some surgeons use a drop of milky prednisolone acetate ( $1 \%$ suspension) to help delineating the flap edges and make sure the flap is in the correct position. ${ }^{13}$ With the microcapillary sign of perfect alignment, the surgeons may not need this suspension, which carries a risk of migrating underneath the flap.

Further studies are needed to confirm the reproducibility of eliciting this sign using different flap architecture settings or different femtolaser platforms.

In summary, capillary action is used in many physical science applications, but now has significance in new refractive procedures using FS LASIK. The microcapillary sign of perfect alignment appears if the flap border forms a perfectly thin and regular gutter to act as a microcapillary. It also documents a regular smooth bed with no tissue loss.

\section{Conclusion}

We present an observational sign, using the effect of the microcapillary action, to ensure perfect precision and good alignment of the colrneal flap in FS LASIK.

\section{Acknowledgment}

Presented at the Alcon WaveLight ${ }^{\circledR}$ Technology Users Meeting 2015, June 19-21, Hamburg, Germany.

\section{Disclosure}

The authors report no conflicts of interest in this work.

\section{References}

1. de Gennes P-G, Brochard-Wyart F, Quere D. Capillarity and Wetting Phenomena: Drops, Bubbles, Pearls, Waves. New York: SpringerVerlag; 2004:49-53.

2. Batchelor GK. An Introduction to Fluid Dynamics. Cambridge Mathematical Library. Cambridge: Cambridge University Press; 1967:67.

3. Zhmud BV, Tiberg F, Hallstensson K. Dynamics of capillary rise $J$ Colloid Interface Sci. 2000;228:263-269.

4. Bico J, Quere D. Rise of liquids and bubbles in angular capillary tubes. J Colloid Interface Sci. 2002;247:162-166.

5. Garg A. Femtosecond laser: current technology and future prospects. In: Garg A, Alió JL, Donnenfeld ED, editors. Femtosecond Laser Techniques and Technology. Daryaganj, New Delhi: Jaypee Brothers Medical; 2012;1-3.

6. Sachdev MS, Khurana C. Femtosecond lasers in ophthalmology. In: Garg A, Alió JL, Donnenfeld ED, editors. Femtosecond Laser Techniques and Technology. Daryaganj, New Delhi: Jaypee Brothers Medical; 2012;28-33.

7. Espandar L, Meyer J. Intraoperative and postoperative complications of laser in situ keratomileusis flap creation using IntraLase femtosecond laser and mechanical microkeratomes. Middle East Afr J Ophthalmol. 2010;17:56-59.

8. Jacobs JM, Taravella MJ. Incidence of intraoperative flap complications in laser in situ keratomileusis. J Cataract Refract Surg. 2002;28: 23-28.

9. Sarayba MA, Ignacio TS, Binder PS, Tran DB. Comparative study of stromal bed quality by using mechanical, IntraLase femtosecond laser 15- and 30-kHz microkeratomes. Cornea. 2007;26:446-451.

10. Kim JH, Lee D, Rhee KI. Flap thickness reproducibility in laser in situ keratomileusis with a femtosecond laser: optical coherence tomography measurement. J Cataract Refract Surg. 2008;34:132-136.

11. Ahn H, Kim JK, Kim CK, et al. Comparison of laser in situ keratomileusis flaps created by 3 femtosecond lasers and a microkeratome. $J$ Cataract Refract Surg. 2011;37:349-357.

12. Perez EP, Viramontes B, Schor P, Miller D. Factors affecting corneal strip stroma-to-stroma adhesion. J Refract Surg. 1998;14:460-462.

13. Kanellopoulos AJ. Femtosecond LASIK: practical pearls. In: Garg A, Alió JL, Donnenfeld ED, editors. Femtosecond Laser Techniques and Technology. Daryaganj, New Delhi: Jaypee Brothers Medical; 2012:4-18.
Clinical Ophthalmology

\section{Publish your work in this journal}

Clinical Ophthalmology is an international, peer-reviewed journal covering all subspecialties within ophthalmology. Key topics include: Optometry; Visual science; Pharmacology and drug therapy in eye diseases; Basic Sciences; Primary and Secondary eye care; Patient Safety and Quality of Care Improvements. This journal is indexed on

\section{Dovepress}

PubMed Central and CAS, and is the official journal of The Society of Clinical Ophthalmology (SCO). The manuscript management system is completely online and includes a very quick and fair peer-review system, which is all easy to use. Visit http://www.dovepress.com/ testimonials.php to read real quotes from published authors. 